\title{
Bacteriophages in Natural and Artificial Environments
}

\author{
Steven Batinovic ${ }^{1,+}{ }^{\oplus}$, Flavia Wassef ${ }^{1,+}$, Sarah A. Knowler ${ }^{1}{ }^{\mathbb{D}}$, Daniel T.F. Rice ${ }^{1}$, \\ Cassandra R. Stanton ${ }^{1}$, Jayson Rose ${ }^{1}$, Joseph Tucci ${ }^{2}{ }^{-}$, Tadashi Nittami ${ }^{3}$, Antony Vinh ${ }^{1}$, \\ Grant R. Drummond ${ }^{1} \oplus$, Christopher G. Sobey ${ }^{1}$, Hiu Tat Chan ${ }^{1}$, Robert J. Seviour ${ }^{1}$, \\ Steve Petrovski ${ }^{1, *, \ddagger}$ and Ashley E. Franks ${ }^{1, \ddagger(\mathbb{D}}$ \\ 1 Department of Physiology, Anatomy \& Microbiology, La Trobe University, Bundoora, VIC 3086, Australia \\ 2 Department of Pharmacy \& Biomedical Sciences, La Trobe University, Bendigo, VIC 3550, Australia \\ 3 Division of Materials Science and Chemical Engineering, Yokohama National University, \\ Yokohama 240-8501, Japan \\ * Correspondence: steve.petrovski@latrobe.edu.au; Tel.: +61-03-9479-2397 \\ $\dagger$ These authors equally contributed to this work. \\ $\ddagger$ These authors equally contributed to this work.
}

Received: 9 June 2019; Accepted: 10 July 2019; Published: 12 July 2019

check for updates

\begin{abstract}
Bacteriophages (phages) are biological entities that have attracted a great deal of attention in recent years. They have been reported as the most abundant biological entities on the planet and their ability to impact the composition of bacterial communities is of great interest. In this review, we aim to explore where phages exist in natural and artificial environments and how they impact communities. The natural environment in this review will focus on the human body, soils, and the marine environment. In these naturally occurring environments there is an abundance of phages suggesting a role in the maintenance of bacterial community homeostasis. The artificial environment focuses on wastewater treatment plants, industrial processes, followed by pharmaceutical formulations. As in natural environments, the existence of bacteria in manmade wastewater treatment plants and industrial processes inevitably attracts phages. The presence of phages in these environments can inhibit the bacteria required for efficient water treatment or food production. Alternatively, they can have a positive impact by eliminating recalcitrant organisms. Finally, we conclude by describing how phages can be manipulated or formulated into pharmaceutical products in the laboratory for use in natural or artificial environments.
\end{abstract}

Keywords: bacteriophage; environment; human body; phage therapy; phage biocontrol; soil; water; wastewater; pharmaceutical products

\section{Introduction}

With advances in DNA sequencing and genomics over the last decade, microbiome research has increased at an exponential rate [1]. The $16 \mathrm{~S}$ ribosomal RNA gene sequencing data generated have aided our understanding of natural bacterial community biodiversity. Metagenomic studies with complex communities have elucidated additional genome sequences, not only from prokaryotes but also eukaryotes and viruses [1]. However, understanding the ecological implications of such data can be highly challenging [1]. A microbial community can work together in mutualistic and antagonistic relationships to perform a defined function, but this may be disrupted if the stability of that community changes. For example, change to the composition of the microbiome in the human body is known to impact on other biological functions, including the immune system and mood [2,3]. Such shifts in community balance can be responses to a range of both exogenous and endogenous parameters, including exposure to bacteriophage (or phage). It is estimated that there are $10^{31}$ phage particles on 
earth, ten-fold more than bacterial population estimates, making phages the most abundant biological entities in the biosphere [4].

Phages infect their host by a range of biochemically diverse host surface receptors, such as carbohydrates, lipopolysaccharides, and proteins $[5,6]$. The phage host range is generally determined by how specifically the phage interacts with the host receptor, such that recognition of a highly unique region can lead to a narrow host range where a phage may be capable of infecting only a single host species or strain $[5,6]$.

Phage life cycles are categorized into two groups which are lytic and temperate. When the lytic phage genome is injected into its host, it initiates processes that hijack the host metabolic systems to ultimately produce multiple viral progenies, which are then released from the host utilizing phage encoded lytic enzymes. These progenies are able to infect new hosts and repeat the lytic cycle (Figure 1). Temperate phage infection may lead to the aforementioned lytic cycle, or alternatively a lysogenic lifecycle, where the phage becomes a prophage by integrating its genetic material into the host genome or forms either circular or linear plasmid within the host cytoplasm. The prophage replicates in synchrony with the host genome until its lytic cycle is induced (Figure 1) [7]. Prophage integration often provides immunity from a superinfection, which is a secondary infection of phages, due to the expression of phage resistance genes by the prophage [8]. This resistance arises through several mechanisms including prophage mediated changes in cell surface receptors which prevents subsequent phage attachment [9]. This immunity can protect a host against phages that are close (homotypic defense) or distant relatives (heterotypic defense) [10].

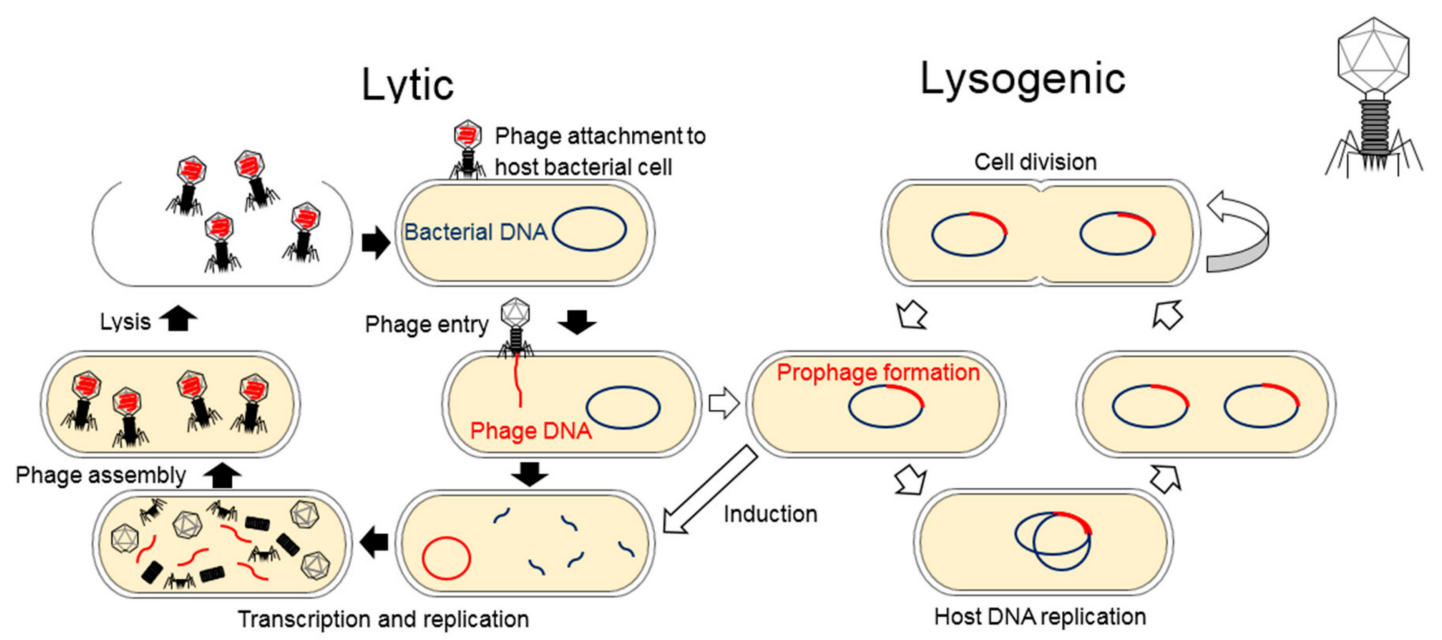

Figure 1. Bacteriophage Lifecycle: Lytic phages attach and infect a bacterial cell which results in the reproduction of phages and lysis of the cell host and this lysogenic cycle results in the integration of a phage genome into the bacterial genome. Some lysogenic phages do not integrate into the genome and remain in the cell as a circular or linear plasmid (not depicted here).

Given the underlying flaws of lysogenic phages, in relation to acquisition of virulence factors and host immunity to superinfection, lytic phages present themselves as attractive candidates for phage therapy or biocontrol. Furthermore, lytic phages can markedly alter microbial communities and exploit their broader functions as this mini review will demonstrate. It will highlight the presence and role of phages in both natural and artificial environments and discuss important impacts phages have on their microbial communities (Figure 2). We show that the impact of lytic phages can be both beneficial and detrimental, which highlights the importance of studying phage communities as an integral part of microbial ecology. 


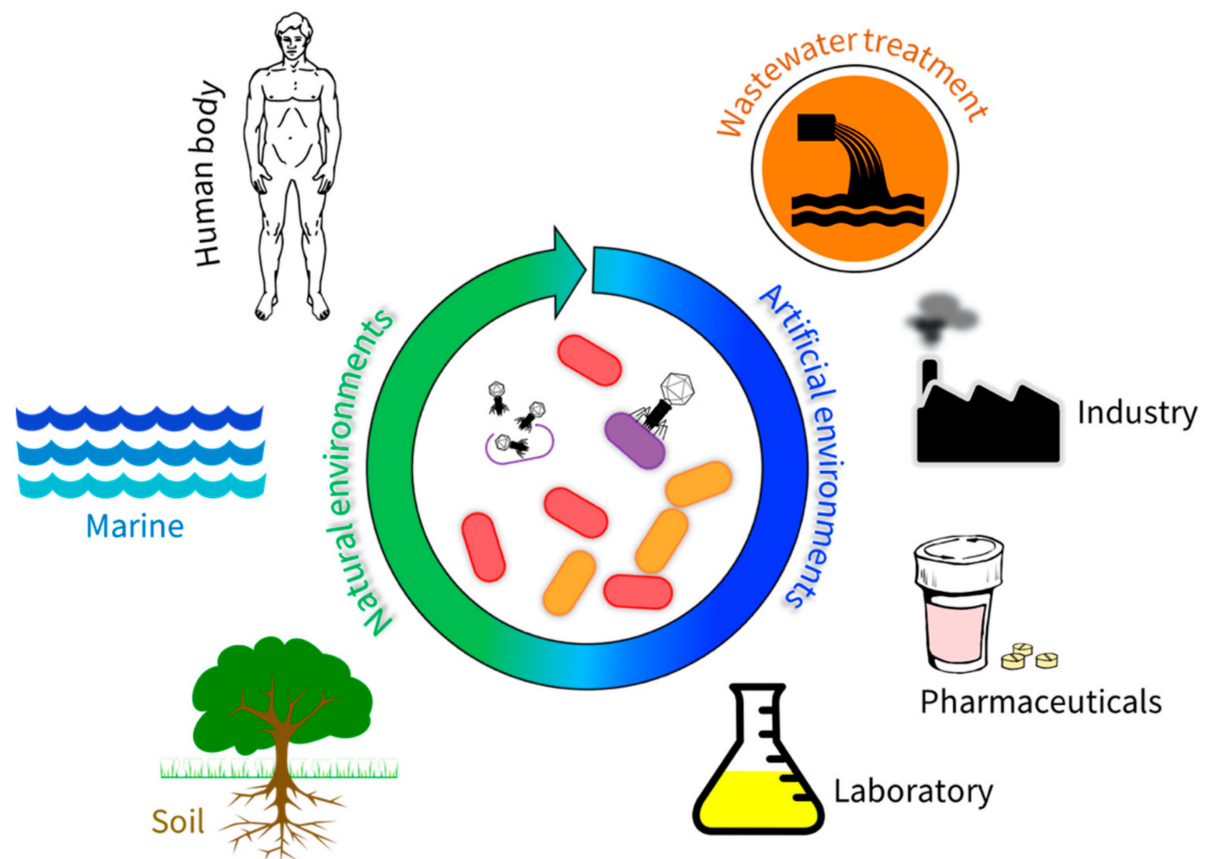

Figure 2. Bacteriophages in natural and artificial environments: The significance of phages in natural environments lies in their ability to replicate within their host, thus impacting the diversity of bacterial communities. Within the human body, phages function to protect against pathogenic bacteria. Ocean waters contain $4 \times 10^{30}$ viruses, making it the largest phage reservoir. Soil phages influence nutrient cycling capabilities and symbioses between plant roots and bacteria. In artificial environments, the ability of phages to mediate bacterial growth can be exploited for a range of uses, due to their specificity and how readily they can be genetically modified. In wastewater treatment, phages can be used to impact the bacterial communities present, thus increasing the efficiency of this process. Industrial applications of phages include control of foodborne pathogens and decreasing the number of problematic bacteria in the petroleum industry. Pharmaceutical uses for phages are currently limited, but this is likely to change as the efficacy of antibiotics reduces and phage efficacy and specificity are improved in the laboratory.

\section{Bacteriophages in Natural Environments}

\subsection{Bacteriophages Within the Human Body}

The human body is colonized with over $10^{12}$ bacteria [11]. Most of these reside within the gut and have been the focus of host-microbiota research for the past decade [12,13]. Phages are also ubiquitous to body surfaces, including the skin, oral cavity, lungs, intestines, and urinary tract and they represent a natural predator to this extensive microbiome, outnumbering bacteria (by at least 10-fold) and play significant roles in shaping the composition of the bacterial communities within various bodily compartments [14-17]. Moreover, it has been demonstrated that phages can penetrate the epithelial lining of these structures via rapid directional transcytosis providing them with access to both vesicular and cytosolic compartments of eukaryotic cells [14,18-20]. It is estimated that 31 billion bacteriophage particles undergo transcytosis across the epithelial cells of the gut into the human body every day which means that there are ample opportunities for modulation of host cell signaling [14].

Mucosal surfaces are the main zones where microbes directly interact with their human hosts [21]. Hence, the mucus layers not only serve as the key points of entry for pathogenic microorganisms, but they are also heavily colonized by symbiotic bacteria that contribute additional genetic and metabolic potential to the host [21]. These resident symbionts benefit from increased nutrient availability, as well as the opportunity for both vertical transmission and increased dissemination [22-26]. Also residing within the mucus layer are bacteriophages, which can bind to mucin glycoproteins via 
immunoglobulin (Ig)-like domains in their capsids in a process termed "bacteriophage adherence to mucin" (BAM). BAM is thought to serve two important functions in the regulation of host-bacteria interactions. First, by accommodating bacteriophages with lytic activity, it provides the host with protection against pathogenic bacteria that might otherwise kill beneficial bacterial species or cause localized or systemic infections [27]. Indeed, there is evidence that, in response to pathogenic bacterial strains, the gut epithelium can actively modulate BAM and the composition of bacteriophages via hypersecretion of mucin and/or alteration of mucin glycosylation patterns in an effort to subvert microbial adherence and survival [28-30]. Second, mucus provides an environment for lysogenic bacteriophages to establish conditional symbiotic relationships with bacteria that are beneficial to their human hosts [31]. Integrated prophages frequently express genes that increase the fitness or virulence of their bacterial strain and protect them from infection of lytic phages. As free phages, they may also benefit their bacterial host strain by killing related bacteria that would otherwise represent competitors [32,33]. Indeed, studies have shown that intestinal commensal bacteria carrying prophage DNA produce infectious virions that limit interspecies competition $[34,35]$. Conversely, there is also evidence that under certain conditions (e.g., inflammatory stress) phage populations with lytic activity against beneficial members of the bacterial community are expanded, resulting in depletion of beneficial bacterial strains and expansion of pathogenic bacteria. The "dysbiosis" that results is potentially an important cause of acute and chronic illnesses [12,21,23,36,37].

Although phages are unable to directly infect eukaryotic cells, they, nonetheless, represent foreign bodies capable of triggering immune responses [38]. In some instances where phages are internalized into eukaryotic cells, they are uncoated, and their nucleic acids are released and have the potential to activate an immune response [39]. Toll-like receptors (TLRs) are one, among several, mechanisms where pathogen associated molecular patterns (PAMPs) are recognized [40]. In this context, TLR9, specifically, is able to recognize viral DNA after phagocytosis or transcytosis of phages [41]. When internalized, phage particles are either degraded or transported throughout the cell where transcription and translation of nucleic acids may occur and lead to cytokine production. It has been shown that there are positive effects of phage anti-inflammatory properties upon bacterial infection, however, this postulates that phages may heighten bacterial fitness and virulence by dampening immune responses [42]. Currently, the consequences of phage-mediated activation of immunity are unclear. However, it is conceivable that disruptions to what might be considered a "normal" phage population within a body compartment could lead to an inappropriate inflammatory response that gives rise to disease. Such disruptions might occur due to conditions associated with immunodeficiencies $[43,44]$; infections, dysbiosis or antibiotic treatments that cause lysis and release of phages from certain bacterial strains; and even changes in diet (e.g., switching from a low fat to a high fat diet) [45-47]. Indeed, emerging research has shown that inflammatory bowel disease (IBD) is associated with elevated levels of double-stranded DNA (dsDNA) phages and that such changes in the abundance and diversity of intestinal phages were independent of changes in the host bacterial communities [48-50]. This suggests that phages may directly contribute to the inflammation associated with IBD. Likewise, it was shown that changes to the composition of intestinal phage populations precede the development of type 1 diabetes in children [51]. This latter study further identified the specific phage strains that correlated with the onset of the disease as members of Microviridae, Myoviridae, and Podoviridae families and suggested there may be a phage component to the development of autoimmunity [51]. Finally, the administration of antibiotics induced transcription of genes associated with induction of lytic intestinal prophage replication, thus contributing to inflammation while also markedly altering both phage and bacterial intestinal communities [46,47].

It is also possible that changes in the phage population could have a beneficial effect on immune function by serving as a warning of an impending bacterial infection. Innate lymphoid cells (ILCs) are enriched at mucosal surfaces and employ fundamental defensive functions. The ILCs do not consist of antigen receptors, do not undergo clonal selection or expansion when stimulated, and are involved in repair responses in the presence of infection [52]. A seminal discovery showed that 
phages bind to TLRs via pathogen recognition and work in concert with neutrophils to promote efficient bacterial clearance during acute pneumonia [30]. Moreover, this study revealed that in the absence of neutrophils and myeloid cells, the immune system was unresponsive to phage treatment, thereby, prolonging infection which in turn suggested an "immunophage synergistic" relationship. Furthermore, phages have been shown to play a vital role in tumor regression via activation and recruitment of tumor-associated macrophages and neutrophils [53]. Similarly, antibiotic-resistant drugs have been an increasing threat to the treatment of infectious diseases. For example, the correlation of anomalous phage community composition to disease status suggests that phages could be utilized as biomarkers for the early detection of disease [54]. Studies have demonstrated that during the early onset of infection, phage treatment not only prevents bacterial invasion of epithelial cells, but also limits propagation and reduces immune cell recruitment [55]. If immune-modulating properties of phages can be validated, it is possible that phages could influence both host and bacterial interactions with each other and with the outcome of phage therapeutic interventions. The study of phage communities within the human microbiota is an emerging field, and much work is still needed to fully understand the impact of these resident viruses on health and disease. Indeed, such knowledge has the potential to unearth new biomarkers and therapeutics for a wide range of human diseases.

\subsection{Bacteriophages in Marine Environments}

Oceans are one of the most important and the largest environment on the planet, covering over $70 \%$ of the earth's surface and providing approximately half of the world's oxygen generation [56]. As a result, they encompass some of the most unique and complex ecosystems of any natural environment. This is also true of the microbes (including bacteria) of these communities which comprise $90 \%$ of the biomass of the ocean, dominating in terms of their abundance, diversity and metabolic function $[57,58]$. The viral portion of these communities is equally or more diverse and abundant [56]. It is estimated that phages are the most biologically abundant entities on the planet based largely on extrapolating the estimated numbers of viruses in our oceans. It is predicted ocean waters contain $4 \times 10^{30}$ viruses in total, thus, outnumbering bacteria and archaea by more than 15 -fold, with phages being the dominant viral group [56]. Because of this diversity and abundance, studies that are based around the virome of marine environments have been well documented and many recent reviews on phages in the surface layers of marine environments are available [56,57,59-65]. Some of their key findings are summarized here.

While studies have revealed phages to be the most abundant biological entities in oceans, taxonomic data is unavailable for approximately $60 \%$ of these, illustrating that little is still known about their diversity [66]. Among those for which taxonomic data is available, phages belonging to the order Caudovirales are the most abundant in surface layers of marine environments $[67,68]$. The order Caudovirales consists of double stranded DNA and tailed phages, which is split into three families, Siphoviridae, Myoviridae, and Podoviridae $[69,70]$ based on differences in morphology (Myoviridae contain long contractile tails, Siphoviridae contain long noncontractile tails, and Podoviridae contain short noncontractile tails). However, at the genome level they can be diverse and share no DNA sequence similarity. The most abundant of these is the Siphoviridae phage, which is not limited to the marine environments but also to many other habitats [71,72].

More recently, an emerging focus has been placed on phages in deep-sea environments characterized by extreme conditions including the recently established Global Ocean Viromes 2.0 dataset [73]. This work greatly expands on the existing body of knowledge surrounding these largely unexplored extreme regions including those of hydrothermal vents, cold temperatures, low light, low oxygen, and high pressure. Interestingly, the broad composition seems to be similar to phage populations seen in other marine environments, with Caudovirales dominating [73,74]. The main difference between surface-layer and deep-sea habitats, however, is the abundance of temperate phages in the latter [75]. It is thought that with such low host cell diversity, a small number of temperate phages dominate the environment, and thus it is likely that they have a strong impact on the bacterial 
communities there. More studies are required to confirm their potential ecological impact within the two different habitats.

\subsection{Bacteriophages in Soil}

In comparison to marine environments, the soil virome remains relatively understudied [76]. Soil constitutes a significant proportion of the global biome and plays a key role in biogeochemical process including the turnover of carbon, nitrogen, and phosphorous (reviewed in [77]). Critical to these processes is a complex and diverse microbiome including bacteria, archaea, and fungi. These communities are distributed heterogeneously in soils such that microbial communities within bulk soil and plant roots can be vastly different in composition and abundance [78]. Collectively, they play crucial roles in the maintenance of soil quality and have tangible impacts on plant growth. Bacteria are amongst the most significantly represented microorganisms within the soil [79]. Given the nature of the phage-host relationship, it is likely bacteriophages exert an important influence by regulating bacterial population dynamics and facilitating horizontal gene transfer by transduction and transformation.

Difficulties associated with extraction of viruses from soil have traditionally hindered the investigation of phages in this environment. Studies exploring phage densities in a range of soil types at different geographical locations have used epifluorescence microscopy or transmission electron microscopy (TEM) to estimate VLP (virus-like particle) numbers [80-82]. Their number has been reported to be in the order of $10^{9}$ per g of dry soil, with variance limited to an order of magnitude across diverse soil types globally [83]. The virus-to-bacterium (VBR) ratio, however, appears to significantly differ depending on the soil type, where virus counts are 10- to 100-fold lower than bacteria in desert and agricultural soils, and 1000-fold higher than bacteria in Antarctic soil [83]. This contrasts to the more homogenous marine environment that shows a much narrower VBR ratio with an average of approximately 10-fold higher abundance of virus numbers as compared with those of bacteria [84]. The relative heterogeneity of soil is thought to account for the substantial variance seen in soil virome load, with moisture content, $\mathrm{pH}$, and temperature being the key factors that control viral abundance and stability [83]. Furthermore, handling and processing of different environmental samples in the field and laboratory may also affect apparent VBR counts, and it is likely that strict standardization of methods between different studies may shed further light on the relative abundance of the soil virome.

The diversity of the virome in different soils seems to reasonably reflect the corresponding diversity of the bacteriome. A TEM-based study of six distinct soil types in Delaware demonstrated that, on average, tailed viruses were the most abundant $(\sim 80 \%)$ type in most soils [81]. This is in contrast to another TEM-based study in Scotland where tailed viruses only accounted for $\sim 5 \%$ of the total viral population, whereas, soils were abundant in viruses with a small spherical morphology [82]. While conclusions on diversity have so far primarily been based on microscopy-based methods (TEM), more recent metagenomics-based approaches will be required to uncover the true diversity across varied soil types $[85,86]$.

The ecological significance of phages in soil, as with viruses in other environments, probably lies in their ability to mediate bacterial growth rates and selectively impact the diversity of bacterial soil communities. It is not surprising that different phages play different roles in individual soil niches. Phages have been implicated in mediating biogeochemical properties of soil through the control of bacterial abundance and hence nutrient cycling capabilities [87], while phages located within the root-adjacent rhizosphere appear to influence the efficacy of symbioses between plant roots and bacteria $[88,89]$. Soil phages have also been applied in biocontrol protocols which is an elegant alternative to more traditional techniques for treating plant disease. This type of approach has already been successfully implemented in phage therapy to control the bacterial plant pathogen Dickeya solani, which is the cause of blackleg and rot in potato [90]. Ultimately, the development and standardization of methodologies for the extraction and investigation of viral assemblies from soils will continue to unravel new phenomena, and novel opportunities for the use of soil phages. 


\section{Bacteriophages in Artificial Environments}

\subsection{Bacteriophages in Wastewater Treatment Plants}

The activated sludge wastewater treatment process is the largest biotechnological process in existence. It utilizes a selected bacterial community to reduce the levels of organic and inorganic compounds so that treated water no longer represents an environmental threat from eutrophication of rivers and lakes [91]. The biomass is organized distinctively as aggregates called flocs. Briefly, this process consists of the introduction of influent into an aeration basin where the wastewater is aerated, in order to promote microbial growth and aggregate formation. Then, this is passed into secondary clarifiers where the biomass flocs, now increased as a consequence of growth settle rapidly, and the liquid phase are removed. The key feature of the process is that most of the settled biomass is then recycled to the head of the plant. Since it contains the populations best suited to deal with the incoming influent, the activated sludge process is rapid and occupies a small footprint. Some of the biomass is discarded to maintain the biomass concentration at a predetermined level, and this control of sludge age is the main way the process is controlled.

Phages are highly abundant and diverse in activated sludge, with a predicted concentration ranging from $10^{8}$ to $10^{9}$ virus-like particles per $\mathrm{ml}$ of mixed liquor [92]. This high abundance of virus, mainly consisting of members of the Siphoviridae family, has received further support from a metagenomic study where $36 \%$ more viral DNA was found there as compared with soil, plant-associated, and other engineered systems [93]. Despite an understanding of the activated sludge process and the viruses involved, little research into phage communities had been conducted prior to 2011 [94]. With the advent of next-generation DNA sequencing (NGS) of isolated phages and metagenomics studies, this situation has improved [95-106]. It is now clear that the genomes of many bacteria present in activated sludge systems contain CRISPR-Cas regions, suggesting that these have in the past been infected by phage, and therefore their presence makes the problem of determining host/phage relationships in the absence of conventional ability to culture host cells, and consequently phage recovery [107].

Although it is still not clear what impact phages have on the activated sludge community, Brown et al. [106] hypothesized that phages are an important factor impacting their composition, and hence are likely to negatively affect plant performance. Evidence by [108] supported this, and suggested that phages may play an important role in performance deterioration of nitrifying bacteria in activated sludge. They used a lysogenic strain of Nitrosospira multiformis, whose genome was known to contain two prophages. By exposure to stress conditions such as low $\mathrm{pH}$ (an event inherently associated with the oxidation of $\mathrm{NH}_{3}$ ), high temperature, and exposure to toxic chemicals, the lytic cycle of these temperate prophages could be induced. Virion replication led to an increase in their abundances, a corresponding drop in the numbers of N. multiformis, and deterioration in rates of nitrification activity. Phages have also been held responsible for deterioration of the phosphorous removal capacity. Thus, it has been suggested that exposure of Accumulibacter to several stress factors induced the lytic cycle in prophages, known to occur in Accumulibacter genomes $[107,109,110]$. This led to an increase in VLP numbers, a decrease in the cell numbers of Accumulibacter, i.e., a phosphorous accumulating organism, and in the copy numbers of $p p k 1$, the gene responsible for the synthesis of polyphosphate. Consequently, biomass phosphorus uptake rates and intracellular phosphate levels fell, and hence P removal capacity decreased. Barr et al. [111] also presented indirect evidence of phage lysis of Accumulibacter which lead to a decrease in plant performance.

Clarification of what impacts phages in activated sludge might have raised the question of whether they might provide a specific environmental control method for the problematic bacteria found in activated sludge [112]. Proliferation of some bacterial members can lead to the severe global operational problems of bulking and foaming caused mainly by filamentous bacteria [113-115], for which few effective treatment options exist [116]. The idea is to reduce the population levels of these below the threshold needed to sustain a bulking or a foaming event. Considerable interest has been shown in using phage therapy to control episodes of bulking (brought about by highly 
hydrophobic bacteria [117]). Phages lytic for most of these foaming bacteria have been isolated and their genomes sequenced [98-100]. Certainly, under lab conditions, these phages are highly effective in controlling foaming, but much still remains to be learned before these can be used with industrial scale plants [103,105]. For example, no phage has ever been isolated for some widespread foamers, and therefore whether their genomes contain defense cassettes [118] or CRISPR-Cas regions needs to be assessed.

\subsection{Bacteriophages in Industrial Applications}

Phages are a potential solution for the elimination of pathogens in the food production industry. Each year, foodborne hazards, predominantly bacterial, cause 420,000 deaths and an estimated 600 million cases of foodborne infections globally [119]. Phages are used currently in food processing in countries including Canada, Israel, and the USA to target pathogenic organisms such as the serious human pathogens Listeria monocytogenes, Salmonella serotypes, and Escherichia coli 0157:H7 [120]. Another potential application includes treating meats where treatment with phages was found to extend the shelf life of products such as pork and beef steaks as early as 1990 [121,122]. However, these studies were performed under laboratory conditions and later work by the same team found that a phage cocktail was ineffective in lysing targeted Pseudomonas strains, possibly reflecting a mismatch in phage/host specificity [121]. Additionally, the solid nature of the food product is significantly different from the broth medium where phage cocktails are commonly developed [123]. A liquid medium supports motility of both phage and bacterium, thus maximizing the likelihood of phage infection [124]. Increasing phage concentration may be one means of overcoming this obstacle. Multiple studies have reported a linear relationship between phage concentration and the inhibition of bacterial growth [125-127]. A 2016 study observed that an application of $10^{5}$ bacteriophage BPECO19 per E. coli O157:H7 bacterium completely inhibited growth within eight hours, while administration of $10^{4}$ phage particles required $72 \mathrm{~h}$ to similarly inhibit growth [127].

Phages occur naturally in the production of fermented foods including sauerkraut and dairy products such as cheese and yoghurt. Phages promote and enhance the production of sauerkraut by inhibiting undesirable bacterial species [128]. This is not the case with the dairy products where phages impede the lactic acid fermentation, in part because of the thermotolerance of some phages surviving pasteurization [122]. Phages that target Lactobacillus helveticus, which are used to produce cheese, can withstand the standard pasteurization temperature of $72{ }^{\circ} \mathrm{C}$ [129]. While this innate property may be beneficial in other applications, it is a hindrance in the production of fermented dairy products.

As reviewed in other literature [130], microbiologically induced corrosion of stainless-steel equipment arises as bacteria impact the kinetics of oxidation-reduction potential, thus increasing the rate of corrosion. This increase may occur through the formation of a biofilms or the production of hydrogen sulphide (H2S). Phages are being investigated widely in industry as a solution to microbiologically induced corrosion. Sulphate reducing bacteria, including members of the genus Desulfovibrio, are problematic in the petroleum industry as they produce $\mathrm{H}_{2} \mathrm{~S}$, which can then be oxidized to $\mathrm{H}_{2} \mathrm{SO}_{4}$ by chemolithotrophic bacteria [131]. In silico screening for prophage genes encoding endolysins or holins to be engineered into phages to target the problematic Desulfovibrio have been reported [131]. In vitro work found that phages were successful in inhibiting the growth of the biofilm producing Stenotrophomonas maltophilia [132]. As noted by a team utilizing a combination of two phages on sulphate-reducing bacteria that produce $\mathrm{H}_{2} \mathrm{~S}$, the extreme specificity of phages represents a challenge to finding such a phage [133]. 


\subsection{Genetic Engineering Phages in the Laboratory}

The potential applications of phages in natural and artificial environments may have certain limitations. However, with advances in molecular techniques, phages can be genetically modified in vitro to enhance current functions. Here, we discuss several recent approaches and applications of engineered phages for their use in environmental, industrial, and clinical areas. Continued exploration into phage genomics and engineering methods will help to advance their efficacy and function in downstream uses.

As pathogens continue to evolve by becoming resistant to antibiotics, the creation of effective and sensitive treatments is vital. Most naturally occurring phages display a narrow host range, infecting single or a few strains of a given species [6]. This can be problematic for phage therapy as it would be advantageous for a phage to be able to have a broader host range and infect multiple strains of the same genera. Research has been undertaken to alter host ranges of phages to either expand their infectivity or change its host from one strain to another which can lead to the creation of "personal therapeutics", phages that have been engineered to treat a patient's specific bacterial infection. Ando et al. [134] established a simple yet efficient yeast-based platform for the modification of phage host ranges by using common viral scaffolds and gap repair cloning to swap the tail fiber gene, gp17, between the two highly similar coliphages, T3 and T7 [134]. These phages were assembled in Saccharomyces cerevisiae resulting in the switching of host ranges without any decrease in lytic abilities. In another study, Mahichi et al. [135] determined it was possible to create a phage with an expanded host range to target multiple E. coli strains. The tail fiber genes, gp37 and gp38, from a broad-spectrum phage, IP088, were integrated into to a narrow host range $\mathrm{T} 2$ phage by exploiting double-crossover homologous recombination [135]. This resulted in an expanded host range of the T2 phage to include both its original host range with the addition of the IP088 host range. Similarly, Marzari et al. [136], used the filamentous phage, Ike, to increase the host range of filamentous phage, fd, by the addition of a receptor-binding domain that encoded the detection of the bacterial cell wall receptor, N-pili. The recombinant phage, fd, was then able to infect $E$. coli strains with the N-pili. The fd phage has also been engineered to infect Vibrio cholerae in conjunction with the natural host E. coli [137]. This was achieved by fusing a minor coat gene $p I I I$ from the fd phage with a sequence of the orf $U$ gene that encoded the N-terminal of another minor coat protein from another filamentous phage, CTX $\Phi$ [137]. The recombinant phage was successfully able to infect both E. coli and V. cholerae.

While having direct antimicrobial activity, phages can be genetically modified to enhance the mechanism of antibiotics or carry enzymes to enhance their natural abilities. Lu and Collins [138] engineered the phage M13mp18 to overexpress the repressor of a SOS DNA repair system. The overexpression of lexA3 increased the efficacy of quinolone antibiotics, improved the activity of ampicillin and gentamicin antibiotics, reduced emergence of antibiotic resistance, and increased antibiotic-mediated killing of the E. coli strains that had already acquired resistance genes [138]. Aside from increasing antibiotic activity, phages can also be engineered to deliver other compounds including enzymes, which can aid in the dispersal of biofilm formations. The toxin pesticin, produced by Yersinia pestis to kill competing bacteria, pesticin, fused to the N-terminal of T4 phages lysozyme protein to expand its target to cells with pesitcin immunity [139].

Biofilms are complex microbial communities embedded in a matrix of extracellular polysaccharide substances (EPS). They are robust and difficult to degrade, causing persistent bacterial infections. To aid in the disruption of biofilms, the phage T7 was modified to express the enzyme, dispersin B $(d s p B)$, which is known to assist in the degradation of biofilms [140]. The engineered T7 phage encoding $d s p B$ was found to reduce cell counts of $E$. coli two orders of magnitude more than when compared to wildtype T7 [140]. Briers et al. [141], have been successful in generating artilysins, synthetic phage endolysins fused with lipopolysaccharide-destabilising peptides. Artilysins show promising results with decreased survival of Salmonella Typhimurium, Pseudomonas aeruginosa, and Acinetobacter baumanii counts when infected with the recombinant phages carrying artilysins [141]. 
Biosensors are detection tools of biological materials. An example of this is the creation of a reporter phage by inserting a fluorescent marker into a phage genome to produce fluorescence during infection of a specific bacterial host. Through the phage's lytic life cycle and self-dosing ability, the marker will increase in concentration over time as the phage replicates, emitting a signal that can be easily detected. The green fluorescent protein (GFP) is a bioluminescent protein commonly used to measure gene expression and has several advantages including not requiring exogenous substrates to produce fluorescence, being small in size ( $700 \mathrm{bp})$, having long lasting signal time, high stability, and low toxicity. Oda et al. [142], used GFP to develop a phage biosensor for the detection of enterohemorrhagic E. coli O157:H7. The GFP was fused to the C-terminus of the smaller outer capsid protein of the phage PP01 through double-crossover homologous recombination. Fluorescence could be detected within an hour of incubation using fluorescent microscopy [142]. For use in industry, a practical and portable detection method is vital. Vinay et al. [143], developed a "phagosensor" prototype using the HK620 phage to successfully detect E. coli and Salmonella sp. in water samples. The fluorescence gene, gfpmut2, was integrated into the phage genome and fluorescence could be easily measured by a portable flow cytometer to allow simple, onsite detection. This method was fast and sensitive, with detection of bacteria as few as 10 cells $/ \mathrm{mL}$ of seawater with no prior enrichment [143]. The luxCDE-luxAB system has also been used extensively to create reporter phages for the detection of Mycobacterium tuberculosis [144], S. typhimurium [145], E. coli [146], Listeria [147], and Bacillus anthracis [148] through bioluminescence. For bioluminescence to occur, this system requires enzymatic activity of luciferase with the addition of a substrate, luciferin, for expression. Schofield et al. [149] successfully integrated lux $A B$ into the $Y$. pesttis phage $\Phi A 1122$ and detected bioluminescence within $12 \mathrm{~min}$ after inoculation. While signal times and strengths depend on cell density, detection could occur in as little as $1000 \mathrm{Y}$. pestis cells within $60 \mathrm{~min}$ [149]. While sensitive, there were issues with detection of background signals, and further optimization is required to decrease both false positives and negatives.

Recently, the first case of using a genetically engineered phage for human treatment was reported [150]. The phage ZoeJ was modified to have its repressor gene deleted, increasing lytic efficiency. As a part of a cocktail with two other phages, modified ZoeJ $\Delta 45$ was used in combination with antibiotics to successfully treat a chronic and life-threatening M. abscessus subsp. Massiliense infection in a 15-year-old cystic fibrosis patient. While no direct correlation between patient improvement and the use of phage treatment can be made, it is evident that reduced morbidity was seen, and often these chronic infections are associated with high morbidity and mortality. It is also noted that phage replication was seen in vivo over the course of treatment, particularly within the first week [150]. Employing phages, particularly those modified with additional advantages, for future treatment of chronic and antibiotic resistant infections should be encouraged. Further research to understand the biology of phage-host interactions and the optimization of gene editing techniques should continue for further advancement in phage genome editing.

\subsection{Bacteriophage in Pharmaceutical Formulations}

As with the formulation of any pharmaceutical agent into semi-solid dosage forms such as creams or ointments, it is important that phages are incorporated into the transfer vehicle so that there is homogeneity throughout the final product. This ensures consistent delivery of the medicament. An obstacle to the medicinal use of phages is that unlike pharmaceutical drugs, phages are large biological entities which rely on the integrity of their structures, for instance, their tails, for proper biological functioning. An acute example of the importance of the integrity of phage structures for therapeutic applications was seen in the recent PhagoBurn clinical trials in Europe [151], where poor therapeutic efficacy of the phages was reported. This may have resulted from physical damage to the viruses during preparation of the therapeutic dressings used.

To achieve delivery to the epithelia, phages can be formulated into aqueous solutions such as lotions, drops, and sprays; in viscous preparations such as hydrophilic gels; or semi-solid preparations such as creams, ointments, and pastes. The efficacy of formulation, stability and release of phages from 
semi-solid preparations has been shown in vitro [152]. Factors which have been shown to be important in stability are temperature and light exposure, such that optimal stability is achieved when phage formulations were stored in light protected containers at $4{ }^{\circ} \mathrm{C}$ [152]. Another factor of importance is the ionic nature of the semi-solid base. The overall electrostatic charge of phages changes with the $\mathrm{pH}$ of the environment [153], and phage capsids and tails can carry opposite charges [154,155]. Ionic polymers within creams may interact with phages through electrostatic forces. In experimental conditions, differential release of phage from creams of varying ionic nature was seen, with optimal release from nonionic formulations [156]. Formulations thicker than creams, such as ointments and pastes, may not be optimal for the delivery of phage for therapy. Components of pastes, for instance, may impart thickness to the final product, inhibiting the movement of phages formulated within [156].

The effect of preservatives in creams and ointments on phages is an area where little data exists. It has been suggested that some preservatives do affect phages adversely [157], and those which are acidic tend to have a more profound effect [158]. In an extensive study of the effect of preservatives on diverse types of phages, specific preservatives were found to significantly impact the efficacy of phages [156]. Apart from aqueous and semi-solid preparations, phages have been formulated into and shown to be successfully released from solid dosage forms such as pessaries, suppositories, and lozenges. These in vitro experiments demonstrated that phages were stable in these forms if stored protected from light at $4{ }^{\circ} \mathrm{C}$ [156].

In comparison to the therapeutic delivery of phages to the epithelia, systemic, and internal delivery of phages for treatment of sepsis and infection of internal organs and tissues offers greater hurdles. Animal models have demonstrated the capacity of phages to be delivered as injections for systemic sepsis infections [159]. Experiments have also begun to clarify the same immunological issues involved with therapeutic treatment using viruses $[160,161]$. While reports of successful application of phages via injection for treatment of such internal infection in humans have been relatively rare, these studies have been conducted [162-164]. With advocation for their potential to complement or substitute for antibiotics in therapy it is expected that there would be more clinical trials and diverse applications in the future $[165,166]$.

There are challenges in the successful oral administration of phages for therapeutic delivery to the gut and for systemic absorption. As mentioned above, formulations in suppositories have been developed, with this delivery mode having the benefit of avoiding potential phage degradation by stomach acidity [152]. While some phages may be expected to survive the harsh gastric environment, formulation of lyophilized phages with a stomach acid-reducing drug such as a proton pump inhibitor or an $\mathrm{H}_{2}$ receptor antagonist may assist [167]. Furthermore, the technology to spray dry and microencapsulate phages for compression into tablets allows for significant protection against gastric fluid $[168,169]$. These dosage forms, therefore, offer realistic potential for gut and systemic delivery of these agents in a manner equivalent to standard pharmaceutical drugs.

\section{Conclusions}

In this review, we discuss the presence of bacteriophages in the natural and artificial environments. The natural environments explored include the human body, marine environments, and soil. The artificial environments included wastewater treatment systems, industrial applications, and laboratory-based techniques, which include genetic engineering of phages and the development of pharmaceutical products. Phages are present in all environments in coexistance with their bacterial hosts. Understanding phage lifecycles and their interaction with their corresponding host can be beneficial for reducing or eliminating recalcitrant bacterial populations, as well as understanding population dynamics. While there are numerous studies and reviews on phages in their natural environments, less attention has been given to the artificial environments. As further research into this field is conducted, it is likely that the impact of phages in various communities will be better understood. In turn, this knowledge can be exploited for a range of applications. 
Funding: This research received no external research funds.

Conflicts of Interest: The authors declare no conflict of interest.

\section{References}

1. Durrant, M.G.; Bhatt, A.S. Microbiome genome structure drives function. Nat. Microbiol. 2019, 4, 912-913. [CrossRef]

2. Mohajeri, M.H.; Brummer, R.J.M.; Rastall, R.A.; Weersma, R.K.; Harmsen, H.J.M.; Faas, M.; Eggersdorfer, M. The role of the microbiome for human health: From basic science to clinical applications. Eur. J. Nutr. 2018, 57 (Suppl. 1), 1-14. [CrossRef] [PubMed]

3. Mohajeri, M.H.; La Fata, G.; Steinert, R.E.; Weber, P. Relationship between the gut microbiome and brain function. Nutr. Rev. 2018, 76, 481-496. [CrossRef] [PubMed]

4. Mann, N.H. The third age of phage. PLoS Biol. 2005, 3, e182. [CrossRef] [PubMed]

5. Marks, T.; Sharp, R. Bacteriophages and biotechnology: A review. J. Chem. Technol. Biotechnol. 2000, 75, 6-17. [CrossRef]

6. Hyman, P.; Abedon, S.T. Bacteriophage host range and bacterial resistance. In Advances in Applied Microbiology; Elsevier: London, UK, 2010; pp. 217-248.

7. Howard-Varona, C.; Hargreaves, K.R.; Abedon, S.T.; Sullivan, M.B. Lysogeny in nature: Mechanisms, impact and ecology of temperate phages. ISME J. 2017, 11, 1511-1520. [CrossRef]

8. Shabbir, M.A.; Hao, H.; Shabbir, M.Z.; Wu, Q.; Sattar, A.; Yuan, Z. Bacteria vs. bacteriophages: Parallel evolution of immune arsenals. Front. Microbiol. 2016, 7, 1292. [CrossRef]

9. Doss, J.; Culbertson, K.; Hahn, D.; Camacho, J.; Barekzi, N. A review of phage therapy against bacterial pathogens of aquatic and terrestrial organisms. Viruses 2017, 9, 50. [CrossRef]

10. Samson, J.E.; Magadan, A.H.; Sabri, M.; Moineau, S. Revenge of the phages: Defeating bacterial defences. Nat. Rev. Microbiol. 2013, 11, 675-687. [CrossRef]

11. Shkoporov, A.N.; Hill, C. Bacteriophages of the human gut: The "known unknown" of the microbiome. Cell Host Microbe 2019, 25, 195-209. [CrossRef]

12. Qin, J.; Li, R.; Raes, J.; Arumugam, M.; Burgdorf, K.S.; Manichanh, C.; Nielsen, T.; Pons, N.; Levenez, F.; Yamada, T.; et al. A human gut microbial gene catalogue established by metagenomic sequencing. Nature 2010, 464, 59-65. [CrossRef]

13. Glasner, M.E. Finding enzymes in the gut metagenome. Science 2017, 355, 577-578. [CrossRef] [PubMed]

14. Nguyen, S.; Baker, K.; Padman, B.S.; Patwa, R.; Dunstan, R.A.; Weston, T.A.; Schlosser, K.; Bailey, B.; Lithgow, T.; Lazarou, M.; et al. Bacteriophage transcytosis provides a mechanism to cross epithelial cell layers. MBio 2017, 8, e01874-17. [CrossRef] [PubMed]

15. Willner, D.; Furlan, M.; Haynes, M.; Schmieder, R.; Angly, F.E.; Silva, J.; Tammadoni, S.; Nosrat, B.; Conrad, D.; Rohwer, F. Metagenomic analysis of respiratory tract DNA viral communities in cystic fibrosis and non-cystic fibrosis individuals. PLoS ONE 2009, 4, e7370. [CrossRef] [PubMed]

16. Pride, D.T.; Salzman, J.; Haynes, M.; Rohwer, F.; Davis-Long, C.; White, R.A., 3rd; Loomer, P.; Armitage, G.C.; Relman, D.A. Evidence of a robust resident bacteriophage population revealed through analysis of the human salivary virome. ISME J. 2012, 6, 915-926. [CrossRef] [PubMed]

17. Foulongne, V.; Sauvage, V.; Hebert, C.; Dereure, O.; Cheval, J.; Gouilh, M.A.; Pariente, K.; Segondy, M.; Burguiere, A.; Manuguerra, J.C.; et al. Human skin microbiota: High diversity of DNA viruses identified on the human skin by high throughput sequencing. PLoS ONE 2012, 7, e38499. [CrossRef] [PubMed]

18. Keller, R.; Engley, F.B.J. Fate of bacteriophage particles introduced into mice by various routes. Proc. Soc. Exp. Biol. Med. 1958, 98, 577-580. [CrossRef]

19. Frenkel, D.; Solomon, B. Filamentous phage as vector-mediated antibody delivery to the brain. Proc. Natl. Acad. Sci. USA 2002, 99, 5675-5679. [CrossRef]

20. Międzybrodzki, R.; Kłak, M.; Jończyk-Matysiak, E.; Bubak, B.; Wójcik, A.; Kaszowska, M.; Weber-Dabrowska, B.; Łobocka, M.; Górski, A. Means to facilitate the overcoming of gastric juice barrier by a therapeutic staphylococcal bacteriophage A5/80. Front. Microbiol. 2017, 8, 467. [CrossRef]

21. Dethlefsen, L.; McFall-Ngai, M.; Relman, D.A. An ecological and evolutionary perspective on human-microbe mutualism and disease. Nature 2007, 449, 811-818. [CrossRef] 
22. Hooper, L.V.; Midtvedt, T.; Gordon, J.I. How host-microbial interactions shape the nutrient environment of the mammalian intestine. Annu. Rev. Nutr. 2002, 22, 283-307. [CrossRef] [PubMed]

23. Chow, J.; Lee, S.M.; Shen, Y.; Khosravi, A.; Mazmanian, S.K. Host-bacterial symbiosis in health and disease. In Advances in Immunology; Elsevier: London, UK, 2010; pp. 243-274.

24. Hooper, L.V.; Xu, J.; Falk, P.G.; Midtvedt, T.; Gordon, J.I. A molecular sensor that allows a gut commensal to control its nutrient foundation in a competitive ecosystem. Proc. Natl. Acad. Sci. USA 1999, 96, 9833-9838. [CrossRef] [PubMed]

25. Martens, E.C.; Chiang, H.C.; Gordon, J.I. Mucosal glycan foraging enhances fitness and transmission of a saccharolytic human gut bacterial symbiont. Cell Host Microbe 2008, 4, 447-457. [CrossRef] [PubMed]

26. Schluter, J.; Foster, K.R. The evolution of mutualism in gut microbiota via host epithelial selection. PLoS Biol. 2012, 10, e1001424. [CrossRef] [PubMed]

27. Barr, J.J.; Auro, R.; Furlan, M.; Whiteson, K.L.; Erb, M.L.; Pogliano, J.; Stotland, A.; Wolkowicz, R.; Cutting, A.S.; Doran, K.S.; et al. Bacteriophage adhering to mucus provide a non-host-derived immunity. Proc. Natl. Acad. Sci. USA 2013, 110, 10771-10776. [CrossRef]

28. Gerken, T.A. Kinetic modeling confirms the biosynthesis of mucin core 1 ( $\beta$-Gal (1-3) $\alpha$-GalNAc-O-Ser/Thr) O-glycan structures are modulated by neighboring glycosylation effects. Biochemistry 2004, 43, 4137-4142. [CrossRef] [PubMed]

29. Schulz, B.L.; Sloane, A.J.; Robinson, L.J.; Prasad, S.S.; Lindner, R.A.; Robinson, M.; Bye, P.T.; Nielson, D.W.; Harry, J.L.; Packer, N.H.; et al. Glycosylation of sputum mucins is altered in cystic fibrosis patients. Glycobiology 2007, 17, 698-712. [CrossRef]

30. Roach, D.R.; Leung, C.Y.; Henry, M.; Morello, E.; Singh, D.; Di Santo, J.P.; Weitz, J.S.; Debarbieux, L. Synergy between the host immune system and bacteriophage is essential for successful phage therapy against an acute respiratory pathogen. Cell Host Microbe 2017, 22, 38-47. [CrossRef]

31. Rodriguez-Brito, B.; Li, L.; Wegley, L.; Furlan, M.; Angly, F.; Breitbart, M.; Buchanan, J.; Desnues, C.; Dinsdale, E.; Edwards, R.; et al. Viral and microbial community dynamics in four aquatic environments. ISME J. 2010, 4, 739-751. [CrossRef]

32. Johansen, B.K.; Wasteson, Y.; Granum, P.E.; Brynestad, S. Mosaic structure of Shiga-toxin-2-encoding phages isolated from Escherichia coli O157: H7 indicates frequent gene exchange between lambdoid phage genomes. Microbiology 2001, 147, 1929-1936. [CrossRef]

33. Willner, D.; Furlan, M.; Schmieder, R.; Grasis, J.A.; Pride, D.T.; Relman, D.A.; Angly, F.E.; McDole, T.; Mariella, R.P., Jr.; Rohwer, F.; et al. Metagenomic detection of phage-encoded platelet-binding factors in the human oral cavity. Proc. Natl. Acad. Sci. USA 2011, 108 (Suppl. 1), 4547-4553. [CrossRef] [PubMed]

34. Duerkop, B.A.; Clements, C.V.; Rollins, D.; Rodrigues, J.L.; Hooper, L.V. A composite bacteriophage alters colonization by an intestinal commensal bacterium. Proc. Natl. Acad. Sci. USA 2012, 109, 17621-17626. [CrossRef] [PubMed]

35. Reyes, A.; Wu, M.; McNulty, N.P.; Rohwer, F.L.; Gordon, J.I. Gnotobiotic mouse model of phage-bacterial host dynamics in the human gut. Proc. Natl. Acad. Sci. USA 2013, 110, 20236-20241. [CrossRef] [PubMed]

36. Reyes, A.; Haynes, M.; Hanson, N.; Angly, F.E.; Heath, A.C.; Rohwer, F.; Gordon, J.I. Viruses in the faecal microbiota of monozygotic twins and their mothers. Nature 2010, 466, 334-338. [CrossRef] [PubMed]

37. Carding, S.R.; Davis, N.; Hoyles, L. The human intestinal virome in health and disease. Aliment. Pharmacol. Ther. 2017, 46, 800-815. [CrossRef]

38. Majewska, J.; Beta, W.; Lecion, D.; Hodyra-Stefaniak, K.; Klopot, A.; Kazmierczak, Z.; Miernikiewicz, P.; Piotrowicz, A.; Ciekot, J.; Owczarek, B.; et al. Oral application of T4 phage induces weak antibody production in the gut and in the blood. Viruses 2015, 7, 4783-4799. [CrossRef] [PubMed]

39. Górski, A.; Dąbrowska, K.; Międzybrodzki, R.; Weber-Dąbrowska, B.; Łusiak-Szelachowska, M.; Jończyk-Matysiak, E.; Borysowski, J. Phages and immunomodulation. Future Microbiol. 2017, 12, 905-914. [CrossRef]

40. Kawai, T.; Akira, S. Toll-like receptors and their crosstalk with other innate receptors in infection and immunity. Immunity 2011, 34, 637-650. [CrossRef]

41. Janeway, C.A.J.; Medzhitov, R. Innate immune recognition. Annu. Rev. Immunol. 2002, 20, $197-216$. [CrossRef] 
42. Van Belleghem, J.D.; Clement, F.; Merabishvili, M.; Lavigne, R.; Vaneechoutte, M. Pro-and anti-inflammatory responses of peripheral blood mononuclear cells induced by Staphylococcus aureus and Pseudomonas aeruginosa phages. Sci. Rep. 2017, 7, 8004. [CrossRef]

43. Li, H.; Sparks, W.; Bonning, B. Protocols for microapplicator-assisted infection of lepidopteran larvae with baculovirus. J. Vis. Exp. 2008, e889. [CrossRef] [PubMed]

44. Monaco, C.L.; Gootenberg, D.B.; Zhao, G.; Handley, S.A.; Ghebremichael, M.S.; Lim, E.S.; Lankowski, A.; Baldridge, M.T.; Wilen, C.B.; Flagg, M.; et al. Altered virome and bacterial microbiome in human immunodeficiency virus-associated acquired immunodeficiency syndrome. Cell Host Microbe 2016, 19, 311-322. [CrossRef] [PubMed]

45. Howe, A.; Ringus, D.L.; Williams, R.J.; Choo, Z.-N.; Greenwald, S.M.; Owens, S.M.; Coleman, M.L.; Meyer, F.; Chang, E.B. Divergent responses of viral and bacterial communities in the gut microbiome to dietary disturbances in mice. ISME J. 2016, 10, 1217-1227. [CrossRef] [PubMed]

46. Allen, H.K.; Looft, T.; Bayles, D.O.; Humphrey, S.; Levine, U.Y.; Alt, D.; Stanton, T.B. Antibiotics in feed induce prophages in swine fecal microbiomes. MBio 2011, 2, e00260-11. [CrossRef] [PubMed]

47. Johnson, T.A.; Looft, T.; Severin, A.J.; Bayles, D.O.; Nasko, D.J.; Wommack, K.E.; Howe, A.; Allen, H.K. The in-feed antibiotic carbadox induces phage gene transcription in the swine gut microbiome. MBio 2017, 8 , e00709-17. [CrossRef] [PubMed]

48. Anderson, J.; Edney, R.; Whelan, K. Systematic review: Faecal microbiota transplantation in the management of inflammatory bowel disease. Aliment. Pharmacol. Ther. 2012, 36, 503-516. [CrossRef] [PubMed]

49. Norman, J.M.; Handley, S.A.; Baldridge, M.T.; Droit, L.; Liu, C.Y.; Keller, B.C.; Kambal, A.; Monaco, C.L.; Zhao, G.; Fleshner, P.; et al. Disease-specific alterations in the enteric virome in inflammatory bowel disease. Cell 2015, 160, 447-460. [CrossRef]

50. Wagner, J.; Maksimovic, J.; Farries, G.; Sim, W.H.; Bishop, R.F.; Cameron, D.J.; Catto-Smith, A.G.; Kirkwood, C.D. Bacteriophages in gut samples from pediatric Crohn's disease patients: Metagenomic analysis using 454 pyrosequencing. Inflamm. Bowel Dis. 2013, 19, 1598-1608. [CrossRef]

51. Zhao, G.; Vatanen, T.; Droit, L.; Park, A.; Kostic, A.D.; Poon, T.W.; Vlamakis, H.; Siljander, H.; Harkonen, T.; Hamalainen, A.M.; et al. Intestinal virome changes precede autoimmunity in type I diabetes-susceptible children. Proc. Natl. Acad. Sci. USA 2017, 114, E6166-E6175. [CrossRef]

52. Eberl, G.; Colonna, M.; Di Santo, J.P.; McKenzie, A.N. Innate lymphoid cells. Innate lymphoid cells: A new paradigm in immunology. Science 2015, 348, aaa6566. [CrossRef]

53. Eriksson, F.; Tsagozis, P.; Lundberg, K.; Parsa, R.; Mangsbo, S.M.; Persson, M.A.; Harris, R.A.; Pisa, P. Tumor-specific bacteriophages induce tumor destruction through activation of tumor-associated macrophages. J. Immunol. 2009, 182, 3105-3111. [CrossRef] [PubMed]

54. Kutateladze, M.; Adamia, R. Bacteriophages as potential new therapeutics to replace or supplement antibiotics. Trends Biotechnol. 2010, 28, 591-595. [CrossRef] [PubMed]

55. Secor, P.R.; Michaels, L.A.; Smigiel, K.S.; Rohani, M.G.; Jennings, L.K.; Hisert, K.B.; Arrigoni, A.; Braun, K.R.; Birkland, T.P.; Lai, Y.; et al. Filamentous bacteriophage produced by Pseudomonas aeruginosa alters the inflammatory response and promotes noninvasive infection in vivo. Infect. Immun. 2017, 85, e0648-16. [CrossRef] [PubMed]

56. Suttle, C.A. Marine viruses-Major players in the global ecosystem. Nat. Rev. Microbiol. 2007, 5, 801-812. [CrossRef] [PubMed]

57. Azam, F.; Malfatti, F. Microbial structuring of marine ecosystems. Nat. Rev. Microbiol. 2007, 5, 782-791. [CrossRef] [PubMed]

58. Breitbart, M.; Bonnain, C.; Malki, K.; Sawaya, N.A. Phage puppet masters of the marine microbial realm. Nat. Microbiol. 2018, 3, 754-766. [CrossRef]

59. Rohwer, F.; Thurber, R.V. Viruses manipulate the marine environment. Nature 2009, 459, 207-212. [CrossRef] [PubMed]

60. Suttle, C.A. Viruses in the sea. Nature 2005, 437, 356-361. [CrossRef]

61. Paul, J.H.; Sullivan, M.B. Marine phage genomics: What have we learned? Curr. Opin. Biotechnol. 2005, 16, 299-307. [CrossRef]

62. Coutinho, F.H.; Gregoracci, G.B.; Walter, J.M.; Thompson, C.C.; Thompson, F.L. Metagenomics sheds light on the ecology of marine microbes and their viruses. Trends Microbiol. 2018, 26, 955-965. [CrossRef] 
63. Perez Sepulveda, B.; Redgwell, T.; Rihtman, B.; Pitt, F.; Scanlan, D.J.; Millard, A. Marine phage genomics: The tip of the iceberg. FEMS Microbiol. Lett. 2016, 363, fnw158. [CrossRef] [PubMed]

64. Breitbart, M. Marine viruses: Truth or dare. Annu. Rev. Mar. Sci. 2012, 4, 425-448. [CrossRef] [PubMed]

65. Warwick-Dugdale, J.; Buchholz, H.H.; Allen, M.J.; Temperton, B. Host-hijacking and planktonic piracy: How phages command the microbial high seas. Virol. J. 2019, 16, 15. [CrossRef] [PubMed]

66. Holmfeldt, K.; Solonenko, N.; Shah, M.; Corrier, K.; Riemann, L.; Verberkmoes, N.C.; Sullivan, M.B. Twelve previously unknown phage genera are ubiquitous in global oceans. Proc. Natl. Acad. Sci. USA 2013, 110, 12798-12803. [CrossRef] [PubMed]

67. Garin-Fernandez, A.; Pereira-Flores, E.; Glockner, F.O.; Wichels, A. The North Sea goes viral: Occurrence and distribution of North Sea bacteriophages. Mar. Genomics 2018, 41, 31-41. [CrossRef] [PubMed]

68. Mizuno, C.M.; Ghai, R.; Saghai, A.; Lopez-Garcia, P.; Rodriguez-Valera, F. Genomes of abundant and widespread viruses from the deep ocean. MBio 2016, 7, e00805-16. [CrossRef] [PubMed]

69. Ackermann, H.-W. Tailed bacteriophages: The order Caudovirales. In Advances in Virus Research; Elsevier: San Diego, CA, USA, 1998; pp. 135-201.

70. Hurwitz, B.L.; Sullivan, M.B. The Pacific Ocean Virome (POV): A marine viral metagenomic dataset and associated protein clusters for quantitative viral ecology. PLoS ONE 2013, 8, e57355. [CrossRef] [PubMed]

71. Nigro, O.D.; Jungbluth, S.P.; Lin, H.T.; Hsieh, C.C.; Miranda, J.A.; Schvarcz, C.R.; Rappe, M.S.; Steward, G.F. Viruses in the oceanic basement. MBio 2017, 8, e2129-16. [CrossRef]

72. Parmar, K.; Dafale, N.; Pal, R.; Tikariha, H.; Purohit, H. An insight into phage diversity at environmental habitats using comparative metagenomics approach. Curr. Microbiol. 2018, 75, 132-141. [CrossRef]

73. Gregory, A.C.; Zayed, A.A.; Conceicao-Neto, N.; Temperton, B.; Bolduc, B.; Alberti, A.; Ardyna, M.; Arkhipova, K.; Carmichael, M.; Cruaud, C.; et al. Marine DNA viral macro- and microdiversity from pole to pole. Cell 2019, 177, 1109-1123. [CrossRef]

74. Winter, C.; Garcia, J.A.L.; Weinbauer, M.G.; DuBow, M.S.; Herndl, G.J. Comparison of deep-water viromes from the Atlantic Ocean and the Mediterranean Sea. PLoS ONE 2014, 9, e100600. [CrossRef] [PubMed]

75. Williamson, S.J.; Cary, S.C.; Williamson, K.E.; Helton, R.R.; Bench, S.R.; Winget, D.; Wommack, K.E. Lysogenic virus-host interactions predominate at deep-sea diffuse-flow hydrothermal vents. ISME J. 2008, 2, 1112-1121. [CrossRef] [PubMed]

76. Trubl, G.; Jang, H.B.; Roux, S.; Emerson, J.B.; Solonenko, N.; Vik, D.R.; Solden, L.; Ellenbogen, J.; Runyon, A.T.; Bolduc, B.; et al. Soil viruses are underexplored players in ecosystem carbon processing. MSystems 2018, 3, e00076-18. [CrossRef] [PubMed]

77. Smith, P.; Cotrufo, M.F.; Rumpel, C.; Paustian, K.; Kuikman, P.J.; Elliott, J.A.; McDowell, R.; Griffiths, R.I.; Asakawa, S.; Bustamante, M.; et al. Biogeochemical cycles and biodiversity as key drivers of ecosystem services provided by soils. Soil Discuss. 2015, 2, 537-586. [CrossRef]

78. Foster, R. The ultrastructure of the rhizoplane and rhizosphere. Annu. Rev. Phytopathol. 1986, 24, $211-234$. [CrossRef]

79. Roesch, L.F.; Fulthorpe, R.R.; Riva, A.; Casella, G.; Hadwin, A.K.; Kent, A.D.; Daroub, S.H.; Camargo, F.A.; Farmerie, W.G.; Triplett, E.W. Pyrosequencing enumerates and contrasts soil microbial diversity. ISME J. 2007, 1, 283-290. [CrossRef]

80. Ashelford, K.E.; Day, M.J.; Fry, J.C. Elevated abundance of bacteriophage infecting bacteria in soil. Appl. Environ. Microbiol. 2003, 69, 285-289. [CrossRef]

81. Williamson, K.E.; Radosevich, M.; Wommack, K.E. Abundance and diversity of viruses in six Delaware soils. Appl. Environ. Microbiol. 2005, 71, 3119-3125. [CrossRef]

82. Swanson, M.M.; Fraser, G.; Daniell, T.J.; Torrance, L.; Gregory, P.J.; Taliansky, M. Viruses in soils: Morphological diversity and abundance in the rhizosphere. Ann. Appl. Biol. 2009, 155, 51-60. [CrossRef]

83. Williamson, K.E. Soil phage ecology: Abundance, distribution, and interactions with bacterial hosts. In Biocommunication in Soil Microorganisms; Springer: Berlin, Germany, 2011; pp. 113-136.

84. Wommack, K.E.; Colwell, R.R. Virioplankton: Viruses in aquatic ecosystems. Microbiol. Mol. Biol. Rev. 2000, 64, 69-114. [CrossRef]

85. Fierer, N.; Breitbart, M.; Nulton, J.; Salamon, P.; Lozupone, C.; Jones, R.; Robeson, M.; Edwards, R.A.; Felts, B.; Rayhawk, S.; et al. Metagenomic and small-subunit rRNA analyses reveal the genetic diversity of bacteria, archaea, fungi, and viruses in soil. Appl. Environ. Microbiol. 2007, 73, 7059-7066. [CrossRef] [PubMed] 
86. Emerson, J.B.; Roux, S.; Brum, J.R.; Bolduc, B.; Woodcroft, B.J.; Jang, H.B.; Singleton, C.M.; Solden, L.M.; Naas, A.E.; Boyd, J.A.; et al. Host-linked soil viral ecology along a permafrost thaw gradient. Nat. Microbiol. 2018, 3, 870-880. [CrossRef] [PubMed]

87. Allen, B.; Willner, D.; Oechel, W.C.; Lipson, D. Top-down control of microbial activity and biomass in an Arctic soil ecosystem. Environ. Microbiol. 2010, 12, 642-648. [CrossRef] [PubMed]

88. Kleczkowska, J. Genetical changes in Rhizobium bacteria and in their bacteriophages during coexistence. Plant Soil 1971, 35, 47-56. [CrossRef]

89. Hashem, F.; Angle, J. Rhizobiophage effects on nodulation, nitrogen fixation, and yield of field-grown soybeans (Glycine max L. Merr). Biol. Fertil. Soils 1990, 9, 330-334. [CrossRef]

90. Adriaenssens, E.M.; Van Vaerenbergh, J.; Vandenheuvel, D.; Dunon, V.; Ceyssens, P.J.; De Proft, M.; Kropinski, A.M.; Noben, J.P.; Maes, M.; Lavigne, R. T4-related bacteriophage LIMEstone isolates for the control of soft rot on potato caused by 'Dickeya solani'. PLoS ONE 2012, 7, e33227. [CrossRef] [PubMed]

91. Ju, F.; Zhang, T. Bacterial assembly and temporal dynamics in activated sludge of a full-scale municipal wastewater treatment plant. ISME J. 2015, 9, 683-695. [CrossRef]

92. Otawa, K.; Lee, S.H.; Yamazoe, A.; Onuki, M.; Satoh, H.; Mino, T. Abundance, diversity, and dynamics of viruses on microorganisms in activated sludge processes. Microb. Ecol. 2007, 53, 143-152. [CrossRef]

93. Wang, Y.; Jiang, X.; Liu, L.; Li, B.; Zhang, T. High-resolution temporal and spatial patterns of Virome in wastewater treatment systems. Environ. Sci. Technol. 2018, 52, 10337-10346. [CrossRef]

94. Shapiro, O.H.; Kushmaro, A. Bacteriophage ecology in environmental biotechnology processes. Curr. Opin. Biotechnol. 2011, 22, 449-455. [CrossRef]

95. Taylor, S.; Brown, T.L.; Tucci, J.; Lock, P.; Seviour, R.J.; Petrovski, S. Isolation and characterization of bacteriophage NTR1 infectious for Nocardia transvalensis and other Nocardia species. Virus Genes 2019, 55, 257-265. [CrossRef]

96. Dyson, Z.A.; Brown, T.L.; Farrar, B.; Doyle, S.R.; Tucci, J.; Seviour, R.J.; Petrovski, S. Locating and activating molecular 'time bombs': Induction of Mycolata prophages. PLoS ONE 2016, 11, e0159957. [CrossRef]

97. Dyson, Z.A.; Tucci, J.; Seviour, R.J.; Petrovski, S. Three of a kind: Genetically similar Tsukamurella phages TIN2, TIN3, and TIN4. Appl. Environ. Microbiol. 2015, 81, 6767-6772. [CrossRef]

98. Petrovski, S.; Seviour, R.J.; Tillett, D. Characterization of the genome of the polyvalent lytic bacteriophage GTE2, which has potential for biocontrol of Gordonia-, Rhodococcus-, and Nocardia-stabilized foams in activated sludge plants. Appl. Environ. Microbiol. 2011, 77, 3923-3929. [CrossRef]

99. Petrovski, S.; Seviour, R.J.; Tillett, D. Genome sequence and characterization of the Tsukamurella bacteriophage TPA2. Appl. Environ. Microbiol. 2011, 77, 1389-1398. [CrossRef]

100. Petrovski, S.; Seviour, R.J.; Tillett, D. Prevention of Gordonia and Nocardia stabilized foam formation by using bacteriophage GTE7. Appl. Environ. Microbiol. 2011, 77, 7864-7867. [CrossRef]

101. Petrovski, S.; Seviour, R.J.; Tillett, D. Characterization and whole genome sequences of the Rhodococcus bacteriophages RGL3 and RER2. Arch. Virol. 2013, 158, 601-609. [CrossRef]

102. Petrovski, S.; Seviour, R.J.; Tillett, D. Genome sequence and characterization of a Rhodococcus equi phage REQ1. Virus Genes 2013, 46, 588-590. [CrossRef]

103. Petrovski, S.; Tillett, D.; Seviour, R.J. Genome sequences and characterization of the related Gordonia phages GTE5 and GRU1 and their use as potential biocontrol agents. Appl. Environ. Microbiol. 2012, 78, 42-47. [CrossRef]

104. Petrovski, S.; Tillett, D.; Seviour, R.J. Isolation and complete genome sequence of a bacteriophage lysing Tetrasphaera jenkinsii, a filamentous bacteria responsible for bulking in activated sludge. Virus Genes 2012, 45, 380-388. [CrossRef]

105. Liu, M.; Gill, J.J.; Young, R.; Summer, E.J. Bacteriophages of wastewater foaming-associated filamentous Gordonia reduce host levels in raw activated sludge. Sci. Rep. 2015, 5, 13754. [CrossRef]

106. Brown, M.R.; Baptista, J.C.; Lunn, M.; Swan, D.L.; Smith, S.J.; Davenport, R.J.; Allen, B.D.; Sloan, W.T.; Curtis, T.P. Coupled virus-bacteria interactions and ecosystem function in an engineered microbial system. Water Res. 2019, 152, 264-273. [CrossRef]

107. Liu, R.; Qi, R.; Wang, J.; Zhang, Y.; Liu, X.; Rossetti, S.; Tandoi, V.; Yang, M. Phage-host associations in a full-scale activated sludge plant during sludge bulking. Appl. Microbiol. Biotechnol. 2017, 101, 6495-6504. [CrossRef] 
108. Choi, J.; Kotay, S.M.; Goel, R. Bacteriophage-based biocontrol of biological sludge bulking in wastewater. Bioeng. Bugs 2011, 2, 214-217. [CrossRef]

109. Albertsen, M.; Hansen, L.B.; Saunders, A.M.; Nielsen, P.H.; Nielsen, K.L. A metagenome of a full-scale microbial community carrying out enhanced biological phosphorus removal. ISME J. 2012, 6, 1094-1106. [CrossRef]

110. Kunin, V.; He, S.; Warnecke, F.; Peterson, S.B.; Garcia Martin, H.; Haynes, M.; Ivanova, N.; Blackall, L.L.; Breitbart, M.; Rohwer, F.; et al. A bacterial metapopulation adapts locally to phage predation despite global dispersal. Genome Res. 2008, 18, 293-297. [CrossRef]

111. Barr, J.J.; Slater, F.R.; Fukushima, T.; Bond, P.L. Evidence for bacteriophage activity causing community and performance changes in a phosphorus-removal activated sludge. FEMS Microbiol. Ecol. 2010, 74, 631-642. [CrossRef]

112. Thomas, J.; Soddell, J.A.; Kurtböke, D. Fighting foam with phages? Water Sci. Technol. 2002, 46, 511-518. [CrossRef]

113. Wanner, J. Activated Sludge: Bulking and Foaming Control; CRC Press: Boca Raton, FL, USA, 2014.

114. Tandoi, V.; Majone, M.; Rossetti, S. Bulking and foaming control methods. In Activated Sludge Separation Problems: Theory, Control Measures, Practical Experiences; IWA Publishing: London, UK, 2017; Volume 99.

115. Petrovski, S.; Dyson, Z.A.; Quill, E.S.; McIlroy, S.J.; Tillett, D.; Seviour, R.J. An examination of the mechanisms for stable foam formation in activated sludge systems. Water Res. 2011, 45, 2146-2154. [CrossRef]

116. Dunkel, T.; de León Gallegos, E.L.; Bock, C.; Lange, A.; Hoffmann, D.; Boenigk, J.; Denecke, M. Illumina sequencing for the identification of filamentous bulking and foaming bacteria in industrial activated sludge plants. Int. J. Environ. Sci. Technol. 2018, 15, 1139-1158. [CrossRef]

117. Jassim, S.A.; Limoges, R.G.; El-Cheikh, H. Bacteriophage biocontrol in wastewater treatment. World J. Microbiol. Biotechnol. 2016, 32, 70. [CrossRef]

118. Azam, A.H.; Tanji, Y. Bacteriophage-host arm race: An update on the mechanism of phage resistance in bacteria and revenge of the phage with the perspective for phage therapy. Appl. Microbiol. Biotechnol. 2019, 103, 2121-2131. [CrossRef]

119. World Health Organization. WHO Estimates of the Global Burden of Foodborne Diseases; World Health Organization: Geneva, Switzerland, 2015.

120. Cooper, C.J.; Koonjan, S.; Nilsson, A.S. Enhancing whole phage therapy and their derived antimicrobial enzymes through complex formulation. Pharmaceuticals 2018, 11, 34. [CrossRef]

121. Greer, G.G.; Dilts, B.D. Inability of a bacteriophage pool to control beef spoilage. Int. J. Food Microbiol. 1990, 10, 331-342. [CrossRef]

122. Hudson, J.A.; Billington, C.; Carey-Smith, G.; Greening, G. Bacteriophages as biocontrol agents in food. J. Food Prot. 2005, 68, 426-437. [CrossRef]

123. Kazi, M.; Annapure, U.S. Bacteriophage biocontrol of foodborne pathogens. J. Food Sci. Technol. 2016, 53, 1355-1362. [CrossRef]

124. Murray, A.G.; Jackson, G.A. Viral dynamics: A model of the effects of size, shape, motion and abundance of single-celled planktonic organisms and other particles. Mar. Ecol. Prog. Ser. 1992, 89, 103-116. [CrossRef]

125. Worley-Morse, T.O.; Zhang, L.; Gunsch, C.K. The long-term effects of phage concentration on the inhibition of planktonic bacterial cultures. Environ. Sci. Process. Impacts 2014, 16, 81-87. [CrossRef]

126. Worley-Morse, T.O.; Gunsch, C.K. Modeling phage induced bacterial disinfection rates and the resulting design implications. Water Res. 2015, 68, 627-636. [CrossRef]

127. Seo, J.; Seo, D.J.; Oh, H.; Jeon, S.B.; Oh, M.H.; Choi, C. Inhibiting the growth of Escherichia coli O157:H7 in beef, pork, and chicken meat using a bacteriophage. Korean J. Food Sci. Anim. Resour. 2016, 36, 186-193. [CrossRef]

128. Callanan, M.J.; Klaenhammer, T.R. Bacteriophages in Industry. In Encyclopedia of Life Sciences; John Wiley \& Sons, Ltd.: Chichester, UK, 2008.

129. Quiberoni, A.; Suarez, V.B.; Reinheimer, J.A. Inactivation of Lactobacillus helveticus bacteriophages by thermal and chemical treatments. J. Food Prot. 1999, 62, 894-898. [CrossRef] [PubMed]

130. Videla, H.A.; Herrera, L.K. Microbiologically influenced corrosion: Looking to the future. Int. Microbiol. 2005, 8, 169-180. [PubMed]

131. Crispim, J.S.; Dias, R.S.; Vidigal, P.M.P.; de Sousa, M.P.; da Silva, C.C.; Santana, M.F.; de Paula, S.O. Screening and characterization of prophages in Desulfovibrio genomes. Sci. Rep. 2018, 8, 9273. [CrossRef] [PubMed] 
132. Pedramfar, A.; Maal, K.B.; Mirdamadian, S.H. Phage therapy of corrosion-producing bacterium Stenotrophomonas maltophilia using isolated lytic bacteriophages. Anti-Corros. Methods Mater. 2017, 64, 607-612. [CrossRef]

133. Summer, N.S.; Summer, E.; Gill, J.; Young, R. Phage of sulfate reducing bacteria isolated from high saline environment. In Proceedings of the Corrosion 2011, NACE Conference and Expo, Houston, TX, USA, 13-17 March 2011.

134. Ando, H.; Lemire, S.; Pires, D.P.; Lu, T.K. Engineering modular viral ccaffolds for targeted bacterial population editing. Cell Syst. 2015, 1, 187-196. [CrossRef] [PubMed]

135. Mahichi, F.; Synnott, A.J.; Yamamichi, K.; Osada, T.; Tanji, Y. Site-specific recombination of T2 phage using IP008 long tail fiber genes provides a targeted method for expanding host range while retaining lytic activity. FEMS Microbiol. Lett. 2009, 295, 211-217. [CrossRef] [PubMed]

136. Marzari, R.; Sblattero, D.; Righi, M.; Bradbury, A. Extending filamentous phage host range by the grafting of a heterologous receptor binding domain. Gene 1997, 185, 27-33. [CrossRef]

137. Heilpern, A.J.; Waldor, M.K. pIIICTX, a predicted CTXphi minor coat protein, can expand the host range of coliphage fd to include Vibrio cholerae. J. Bacteriol. 2003, 185, 1037-1044. [CrossRef]

138. Lu, T.K.; Collins, J.J. Engineered bacteriophage targeting gene networks as adjuvants for antibiotic therapy. Proc. Natl. Acad. Sci. USA 2009, 106, 4629-4634. [CrossRef]

139. Lukacik, P.; Barnard, T.J.; Keller, P.W.; Chaturvedi, K.S.; Seddiki, N.; Fairman, J.W.; Noinaj, N.; Kirby, T.L.; Henderson, J.P.; Steven, A.C.; et al. Structural engineering of a phage lysin that targets gram-negative pathogens. Proc. Natl. Acad. Sci. USA 2012, 109, 9857-9862. [CrossRef]

140. Lu, T.K.; Collins, J.J. Dispersing biofilms with engineered enzymatic bacteriophage. Proc. Natl. Acad. Sci. USA 2007, 104, 11197-11202. [CrossRef] [PubMed]

141. Briers, Y.; Walmagh, M.; Van Puyenbroeck, V.; Cornelissen, A.; Cenens, W.; Aertsen, A.; Oliveira, H.; Azeredo, J.; Verween, G.; Pirnay, J.P.; et al. Engineered endolysin-based "Artilysins" to combat multidrug-resistant gram-negative pathogens. MBio 2014, 5, e01379-14. [CrossRef] [PubMed]

142. Oda, M.; Morita, M.; Unno, H.; Tanji, Y. Rapid detection of Escherichia coli O157:H7 by using green fluorescent protein-labeled PP01 bacteriophage. Appl. Environ. Microbiol. 2004, 70, 527-534. [CrossRef] [PubMed]

143. Vinay, M.; Franche, N.; Gregori, G.; Fantino, J.R.; Pouillot, F.; Ansaldi, M. Phage-based fluorescent biosensor prototypes to specifically detect enteric bacteria such as E. coli and Salmonella enterica Typhimurium. PLoS ONE 2015, 10, e0131466. [CrossRef]

144. Sarkis, G.J.; Jacobs, W.R.J.; Hatfull, G.F. L5 luciferase reporter mycobacteriophages: A sensitive tool for the detection and assay of live mycobacteria. Mol. Microbiol. 1995, 15, 1055-1067. [CrossRef] [PubMed]

145. Kim, S.; Kim, M.; Ryu, S. Development of an engineered bioluminescent reporter phage for the sensitive detection of viable Salmonella typhimurium. Anal. Chem. 2014, 86, 5858-5864. [CrossRef]

146. Oosterik, L.H.; Tuntufye, H.N.; Tsonos, J.; Luyten, T.; Noppen, S.; Liekens, S.; Lavigne, R.; Butaye, P.; Goddeeris, B.M. Bioluminescent avian pathogenic Escherichia coli for monitoring colibacillosis in experimentally infected chickens. Vet. J. 2016, 216, 87-92. [CrossRef]

147. Schmelcher, M.; Shabarova, T.; Eugster, M.R.; Eichenseher, F.; Tchang, V.S.; Banz, M.; Loessner, M.J. Rapid multiplex detection and differentiation of Listeria cells by use of fluorescent phage endolysin cell wall binding domains. Appl. Environ. Microbiol. 2010, 76, 5745-5756. [CrossRef]

148. Sharp, N.J.; Molineux, I.J.; Page, M.A.; Schofield, D.A. Rapid detection of viable Bacillus anthracis spores in environmental samples by using engineered reporter phages. Appl. Environ. Microbiol. 2016, 82, 2380-2387. [CrossRef]

149. Schofield, D.A.; Molineux, I.J.; Westwater, C. Diagnostic bioluminescent phage for detection of Yersinia pestis. J. Clin. Microbiol. 2009, 47, 3887-3894. [CrossRef]

150. Dedrick, R.M.; Guerrero-Bustamante, C.A.; Garlena, R.A.; Russell, D.A.; Ford, K.; Harris, K.; Gilmour, K.C.; Soothill, J.; Jacobs-Sera, D.; Schooley, R.T.; et al. Engineered bacteriophages for treatment of a patient with a disseminated drug-resistant Mycobacterium abscessus. Nat. Med. 2019, 25, 730-733. [CrossRef] [PubMed]

151. Jault, P.; Leclerc, T.; Jennes, S.; Pirnay, J.P.; Que, Y.-A.; Resch, G.; Rousseau, A.F.; Ravat, F.; Carsin, H.; Le Floch, R.; et al. Efficacy and tolerability of a cocktail of bacteriophages to treat burn wounds infected by Pseudomonas aeruginosa (PhagoBurn): A randomised, controlled, double-blind phase 1/2 trial. Lancet Infect. Dis. 2019, 19, 35-45. [CrossRef] 
152. Brown, T.L.; Thomas, T.; Odgers, J.; Petrovski, S.; Spark, M.J.; Tucci, J. Bacteriophage formulated into a range of semisolid and solid dosage forms maintain lytic capacity against isolated cutaneous and opportunistic oral bacteria. J. Pharm. Pharmacol. 2017, 69, 244-253. [CrossRef] [PubMed]

153. Todd, C. On the electrical behaviour of the bacteriophage. Br. J. Exp. Pathol. 1927, 8, 369.

154. Serwer, P.; Hayes, S.J. Agarose gel electrophoresis of bacteriophages and related particles. I. Avoidance of binding to the gel and recognizing of particles with packaged DNA. Electrophoresis 1982, 3, 76-80. [CrossRef]

155. Serwer, P.; Pichler, M.E. Electrophoresis of bacteriophage T7 and T7 capsids in agarose gels. J. Virol. 1978, 28, 917-928. [PubMed]

156. Brown, T.; Petrovski, S.; Chan, H.T.; Angove, M.J.; Tucci, J. Semi-solid and solid dosage forms for the delivery of phage therapy to epithelia. Pharmaceuticals 2018, 11, 26. [CrossRef]

157. Subils, T.; Aquili, V.; Ebner, G.; Balague, C. Effect of preservatives on Shiga toxigenic phages and Shiga toxin of Escherichia coli O157: H7. J. Food Prot. 2012, 75, 959-965. [CrossRef]

158. Merabishvili, M.; Monserez, R.; van Belleghem, J.; Rose, T.; Jennes, S.; De Vos, D.; Verbeken, G.; Vaneechoutte, M.; Pirnay, J.-P. Stability of bacteriophages in burn wound care products. PLoS ONE 2017, 12, e0182121. [CrossRef]

159. Takemura-Uchiyama, I.; Uchiyama, J.; Osanai, M.; Morimoto, N.; Asagiri, T.; Ujihara, T.; Daibata, M.; Sugiura, T.; Matsuzaki, S. Experimental phage therapy against lethal lung-derived septicemia caused by Staphylococcus aureus in mice. Microbes Infect. 2014, 16, 512-517. [CrossRef]

160. Hodyra-Stefaniak, K.; Miernikiewicz, P.; Drapała, J.; Drab, M.; Jończyk-Matysiak, E.; Lecion, D.; Kaźmierczak, Z.; Beta, W.; Majewska, J.; Harhala, M. Mammalian host-versus-phage immune response determines phage fate in vivo. Sci. Rep. 2015, 5, 14802. [CrossRef]

161. Łusiak-Szelachowska, M.; Żaczek, M.; Weber-Dąbrowska, B.; Międzybrodzki, R.; Kłak, M.; Fortuna, W.; Letkiewicz, S.; Rogóż, P.; Szufnarowsk, i.K.; Jończyk-Matysiak, E.; et al. Phage neutralization by sera of patients receiving phage therapy. Viral Immunol. 2014, 27, 295-304. [CrossRef] [PubMed]

162. Sedallian, P.; Bertoye, A.; Gauthier, J.; Muller, J.M.; Courtieu, A.L. Suppurative meningitis caused by Escherichia coli treated by an intraspinal adapted bacteriophage. Lyon Med. 1958, 90, 509-512. [PubMed]

163. Stroj, L.; Weber-Dabrowska, B.; Partyka, K.; Mulczyk, M.; Wojcik, M. Successful treatment with bacteriophage in purulent cerebrospinal meningitis in a newborn. Neurol. I Neurochir. Pol. 1999, 33, 693-698.

164. Nir-Paz, R.; Gelman, D.; Khouri, A.; Sisson, B.M.; Fackler, J.; Alkalay-Oren, S.; Khalifa, L.; Rimon, A.; Yerushalmy, O.; Bader, R.; et al. Successful treatment of antibiotic resistant poly-microbial bone infection with bacteriophages and antibiotics combination. Clin. Infect. Dis. 2019. [CrossRef] [PubMed]

165. Reindel, R.; Fiore, C.R. Phage therapy: Considerations and challenges for development. Clin. Infect. Dis. 2017, 64, 1589-1590. [CrossRef] [PubMed]

166. Asija, K.; Teschke, C.M. Lessons from bacteriophages part 2: A saga of scientific breakthroughs and prospects for their use in human health. PLoS Pathog. 2018, 14, e1006970. [CrossRef] [PubMed]

167. Brown, T.L.; Petrovski, S.; Hoyle, D.; Chan, H.T.; Lock, P.; Tucci, J. Characterization and formulation into solid dosage forms of a novel bacteriophage lytic against Klebsiella oxytoca. PLoS ONE 2017, 12, e0183510. [CrossRef] [PubMed]

168. Vinner, G.K.; Rezaie-Yazdi, Z.; Leppanen, M.; Stapley, A.G.F.; Leaper, M.C.; Malik, D.J. Microencapsulation of Salmonella-sSpecific bacteriophage Felix $\mathrm{O} 1$ using spray-drying in a $\mathrm{pH}$-responsive formulation and direct compression tableting of powders into a solid oral dosage form. Pharmaceuticals 2019, 12, 43. [CrossRef]

169. Colom, J.; Cano-Sarabia, M.; Otero, J.; Arinez-Soriano, J.; Cortes, P.; Maspoch, D.; Llagostera, M. Microencapsulation with alginate $/ \mathrm{CaCO}_{3}$ : A strategy for improved phage therapy. Sci. Rep. 2017, 7, 41441. [CrossRef]

(C) 2019 by the authors. Licensee MDPI, Basel, Switzerland. This article is an open access article distributed under the terms and conditions of the Creative Commons Attribution (CC BY) license (http://creativecommons.org/licenses/by/4.0/). 